\title{
Embodied Oppression and Psychological Trauma: The Subjugation of O-lan's in Pearl Buck's Novel the Good Earth
}

\author{
Hanan Abbas Hussein \\ Department of English, College of Education for Women \\ University of Baghdad \\ E-mail: hanan.abbas@coeduw.uobaghdad.edu.iq
}

Received: 3/7/2021 Accepted: 4/21/2021 Published: 5/24/2021

\begin{abstract}
The present paper is qualitative; it illustrates the sense of oppression, negligence, and marginalization; Chinese women suffer from in their society. There, women are bound to doing housework and rearing children; they are a mere tool to meet their husbands' pleasures and find concubines when needed. Accordingly, the study examines the sources, and types of psychological trauma experienced by the character O-lan, and later by the oppressors, her husband and his new wife, Wang Lung, in Buck's novel The Good Earth. To meet the objective of the study, Robinson, Smith, \& Segal's (2020) types of trauma will be adopted in the analysis. Such a study help know more about the traditions and values of Chinese society, the role of women there. It further reflects the negative societal consequence $s$ of abusing and humiliating women, and the curse men will gain due to their unjust treatment of their wives. The psychological trauma of O-lan is highly indicated by her husband's speech and behavior. He constantly belittles her role a wife, neglecting her emotions. She keeps her agony and depression till she collapsed.
\end{abstract}

Keywords: Chinese society, embodied oppression, psychological Trauma, Buck's novel the Good Earth

Cite as: Hussein, A. H.(2021). Embodied Oppression and Psychological Trauma: The Subjugation of O-lan's in Pearl Buck's Novel the Good Earth. Arab World English Journal for Translation \& Literary Studies 5 (2) 104 -114. DOI: http://dx.doi.org/10.24093/awejtls/vol5no2.8 


\section{Introduction}

This study focuses on examining the concept of oppression and its types as experienced by women in general and poor women in particular in Chinese society. As concept, oppression was defined by the Social Work Dictionary (as cited in Barker, 2003) as the social act of placing severe restrictions on an individual, group, or institution. The oppressed individual is called the exploited person, deprived of his privileges by the most powerful individual or group.

Pearl Sydenstricker Buck (1892-1973) is one of the prominent American writers who spent most of her life in China. In his novel, The Good Earth, Buck clearly illustrated and explained the trauma and difficulties that resulted from women's sense of oppression in that society, reflecting; as a result of the rigid and strict Chinese culture concerning for women. The pressure towards women is deeply rooted in China, where people believe that heaven is Qian and earth is Kun. To them, the male is considered Qian while the female is Kun. The relationship between Qian and Kun depicts as the distance between heaven and earth, and ultimately between men and women. This is because men are considered superior to women in Chinese society (Peng, 2014).

Women should work hard in the house and be under the complete control of their husbands. Women's role was limited to domestic household and fieldwork. They were deprived of their rights and were treated as bearers of children rather than as wives. They were also obliged to find a concubine or a second wife to their husbands if they cannot conceive in their life. Buck depicted the wrong way women are treated, shedding light on the role of class in such a treatment. For instance, rich women usually own authority and power while poor women are deprived of certain rights. The poor women live in oppression, subjection, and mistreatment (Yao, 1983). However, generally, Chinese women face bitter treatment, pressure, and shame. They are required to obey the orders of men without discussion. Being a woman in China means accepting the hardships of the domestic sphere, and taking care of children.

In China, women are called 'yin', which means 'overcast' or 'shade'. When a woman is married; she should obey her husband like slaves without commenting or complaining. Moreover, being a woman means that all the decisions and opinions concerning their life are rejected. Accordingly, women should listen and follow the orders of males in a family during her life. They should also obey men whether they are their fathers, husbands, brothers, and sons. After the death of their husbands, they should submit and follow her son's orders. In brief, women deprived of confessing their ideas and emotions (Tamney, 2002). Accordingly, the present work examines the sources and types of oppression and psychological trauma experienced by the character O-lan and later by her husband, and his new wife, Wang Lung, in Buck's novel The Good Earth. Such a study helps to learn about the negative consequences of using violence and oppression in generating psychologically/ emotionally traumatic women and, or men. That is, following blindly certain traditions, and values might curse the society as a whole. Thus, the study is to address the following research question; which reads: What are the sources and types of psychological trauma experienced by the character O-lan, and later by the oppressors, her husband and his new wife, Wang Lung, in Buck's novel The Good Earth. 


\section{Theoretical Background \\ Trauma as a Concept}

Terminologically speaking, trauma is of Greek origin, meaning 'wound'. This term was used in earlier ages to refer to physical injuries. In other words, trauma uses to refer mainly to everything that hurts the body of a person and leaves it vulnerable (Raton, 2018).

Generally, trauma defines as a term that is frequently used by people to indicate the psychological and emotional response experienced by people in everyday lives to an event or experience that is deeply distressing or very painful. The definition of trauma, however, is more complicated than this. It cannot simply be defined as ordinary stressful events that one may encounter in his daily life (Raton, 2018).

Also, beside trauma is said to affect the physical and psychological condition of the traumatized person. This is because the prolonged exposure to pressure and stress can lead to an extensive range of physical illnesses, such as exhaustion, headache, sexual dysfunction, etc. Severe and persistent trauma can also lead to various of psychiatric conditions, such as depression and dissociative disorder. Depressions are conditions that are raised due to people's inability to tolerate injustice, leading them to internalize and eliminate all negativity and unpleasant feelings (Raton, 2018). A traumatic experience a person encounters in life is considered a threat to his safety. The demanding situations that face a man in life make him feels depressed and isolated. The more disappointed and helpless he/she feels, the more likely he/she is to be traumatized (Robinson, Smith, \& Segal, 2020).

\section{Types of Trauma}

There are different types of trauma, such as physical abuse, emotional abuse, traumatic grief, physical assault, sexual assault, school assault, racism, neglect, and more. Psychologically, trauma means the result of extraordinary pain, suffering, or stressful events that disrupt the security of life. It makes one feel isolated and entrapped. Psychological trauma puts someone in a place where s/he cannot avoid persistent upsetting emotions, sad memories, and agony. It puts one in a position where s/he feels disconnected and unable to trust other people (Raton, 2018).

\section{Previously Conducted Studies}

Many studies have explored psychological trauma, such as Sarah Blanchette, who focused on the representations of trauma and the mental distress in twentieth-century novels and films. He emphasizes on different ways that marginalized communities, in particular women-coded. Blanchette shows that our mental health is affected when we experience traumatic events and the experiences of mental illness look beyond medicine (Blanchette, 2020). Heidarizadeh offered a great insight of trauma in Margaret Atwood's Cat's Eye through the female characters. He depicted the pain, and the sufferings emerged from the traumatized experiences as seen in their life. He elaborates that man should work hard to change the world of dystopia into a utopia, and by his power, he will exceed all the disastrous of past days. (Heidarizadeh, 2015). Samantha Alongi also explained through Morrison's beautiful language and insightful delivery of her characters and their circumstances, the way the audience are empathizing not only feelings, but also the terrible aspects of society that Morrison is revealing (Alongi, 2009). Kyeong also illustrated the trauma of minority subjects in selected American novels to examine the narrative functions of healing and defiance. He shows the impact of psychological trauma on selfhood emphasizing on the issues of social oppression in Toni Morrison's The Bluest Eye (Hwangbo, 2004). The present study is concerned with the concept of 
psychological trauma, which examined in Buck's certain characters in her novel the Good Earth through adopting Robinson et al.’s (2020) symptoms of psychological trauma.

\section{Robinson et al.'s Symptoms of Psychological Trauma as an Adopted Concept}

Since the present work mainly focuses on examining the symptoms of psychological trauma in the literary work in question, the researcher is to adopt Robinson et al.'s (2020) symptoms of trauma: emotional/psychological trauma, and physical trauma, as shown below:

Emotionally or psychologically, trauma can lead one to experience the following symptoms: Shock and disbelief, hidden anger and mood swings, confusion, guilt and shame, anxiety and fear, withdrawing from others, feeling sad and hopeless, and feeling disconnected and numb. Physical trauma, on the other hand, leads one to suffer from the following symptoms: fatigue, difficulty concentrating, aches and pain, and muscle tension.

\section{Methodology of the Study}

The present study analytically and comparatively examined the novel in question. To meet the objective of the study, which reads, examining the sources and types of psychological trauma experienced by the character O-lan, and later by the oppressors, her husband and his new wife, Wang Lung in Buck's novel The Good Earth, the researcher is to follow the following procedures:

a. skimming the novel to reflect women's oppression in the Chinese society;

b. identifying O-lan's symptoms of psychological trauma following Robinson et al.'s (2020) symptoms;

c. pinpointing O-lan's sources of psychological trauma;

d. stating the roles of O-lan, Lotus, and Lung's aunt as representatives of different women's strata within the Chinese society; and

e. Stating the way the causer of trauma might be the traumatic persons themselves.

\section{Data Analysis and Discussion}

To meet the objective of the study, the researcher is to achieve the above-mentioned procedural points in sequence:

Skimming the novel to reflect women's oppression in the Chinese society;

The Good Earth is a story of Wang Lung's family, which explains the marriage of a character called Wang Lung to O-lan, a poor woman. Wang Lung decided to marry O-lan because his aunt advised him to marry O-lan, saying:

Take her and use her well. She is a good slave, although somewhat slow and stupid; and had I not wished to acquire merit at the temple for my future existence by bringing more life into the world I should have kept her, for she is good enough for the kitchen. (Buck, 1931, p.18)

Through his hard work and his wife's skills, Wang Lung changed his family's position and managed to buy the land from the Hwang family. He rose to the status of a wealthy landowner, wishing his children to keep his land forever. 
Women in a patriarchal society, especially those slaves, are deprived of living an everyday life. This is reflected in the conversation between Wang Lung and his neighbor. That man's words reflect the Chinese notions about women:

When the rich are too rich, there are ways and when the poor are too poor, there are ways. Last winter, we sold two girls and this winter if this one my woman bears a girl, we will sell again. One slave I have kept the first. The others it is better to sell than to kill although there are those who prefer to kill them before they drew breath . (Buck, 1931, p.118)"

\section{Identifying O-lan's symptoms of psychological trauma:}

Selling girls as slaves are common in poor families in the Chinese society; a matter which is represented by the character of O-lan. The psychological trauma of O-lan begins from the first stage in her life as she was sold by her family to become a slave. She came to Hwang house when she was only 10 years old in a year of famine because her family had nothing to eat. Being a slave woman means she lives unbearable pains that affect her mentally and physically. The emotional reactions to oppressions affected and influenced Olan's sociocultural life.

O-lan's initial life completely controlled her mind and behavior. For instance, in the event of the box, Wang Lung and O-lan came out of the house of Hwang's House, O-lan picked up a heavy box and tried to place it on her shoulder, but Wang Lung ordered her to take the basket instead. "She was like a faithful, speechless serving maid" (Buck, 1931). She tried her best to get things done to have his appreciation and passion in return. She spent most of her life in the kitchen or working hard around the field to please her husband. Wang Lung felt happy for her achievements, whether o the house or the farm. He was thankful for O-lan's efforts, but he could not express his feelings because of Chinese customs and beliefs (Rebeca, n.d).

O-lan informed Wang Lung that she was pregnant with her first child. Wang Lung felt delighted when he knew that. O-lan worked hard in the field with her husband during her pregnancy. In her life, Olan experienced difficulty due to the too much concentration and felt confused as she gave birth to a baby while she was working in the farm. During her work, she told Wang Lung, "It is come. I will go into the house. Only bring me a newly peeled reed and slit it that I may cut the child's life from mine" (Buck, 1931). She gave birth to a child enduring pains without anyone's help. As O-lan gave birth to a boy, Wang Lung says, "I will go into the city and buy a pound of red sugar and stir it into boiling water for you to drink" (Buck, 1931). He was delighted and full of hope with the delivery of the boy. O-lan's marriage to Wang Lung opened the gate of wealth and happiness. She helped her husband in farm labor, and then continued her job as a wife and a mother. O-lan and Wang Lung started to save silver in an earthen pot in their wall. Through their hard work, they earned money to buy land from the Hwang family.

O-lan remained in the kitchen to prepare delicious dishes. From the first time of her wedding, she served the guests and Lung's relatives without comments. When Wang Lung praised O-lan for the delicious cooking, she replied, "I have been kitchen slave since I went into the House of Hwang" (Buck, 1931). Olan told Wang Lung the miserable conditions of slaves in rich man's house as a matter of fact. She narrated that by answering him: 
Aye, beaten or carried to a man's bed, as the whim was and not to one man's only but to any that might desire her that night and the young lords bickered and bartered with each other for this slave or that... . (Buck, 1931, p. 133)

O-lan is physically consumed in the life of a 'submissive housewife', 'kitchen slave', 'bearer of children', which reflects the misery and oppressed life of most of the Chinese women especially, those who work as slaves. Her psychological condition resulted in physical pain that negatively affected her for the years to come. O-lan quietly suffered, survived and bore the hardships of life. She achieved the duties quietly:

The earthen floor was swept and the fuel pile replenished. The woman, when he had gone in the morning, took the bamboo rake and a length of rope and with these she roamed the countryside, reaping here a bit of grass and there a twig or a handful of leaves, returning at noon with enough to cook the dinner. It pleased the man that they need buy no more fuel. (Buck, 1931, pp. 27-28)

O-lan suffered from this trauma that has a profound impact on the way she thinks, behaves and feels for a long time afterward. She hid her anger and still, she did all the activities silently. O-lan believed the stereotype of good women in her house could be met by doing the domestic matters perfectly. In this vein, Buck (1931) commented that "she worked in the house and made new clothes for each one and new shoes, and she made coverings of flowered cloth stuffed with warm new cotton for every bed". She worked in a field, cooking, taking care of her children and washing. O-lan did everything while her husband showed his cruel indifference. In this case, O-lan's reaction turned either apathy or hatred, but she endured the pain silently (Peng, 2014). O-lan endured the difficulties of her life which ultimately led her to have a psychological collapse and sickness.

O-lan lived in fear and anxiety during the famine when there was nothing left to eat. Wang's father commanded Wang Lung to kill an Ox, but Wang Lung could not do that. Courageously, O-lan decided to do that by taking a sharp knife and preparing it for a meal. She tried her best to protect her children from hunger and deprivation. However, their lives changed with the severe famine they passed through; a matter that affected mentally their first daughter. Wang Lung addressed her daughter by the name "Poor Fool" (Buck, 1931). He considered the birth of his daughter as a bad omen and a sign of depression. By hearing that, O-lan felt worried and nervous. She rejected the idea of selling her daughter as a slave and suggested killing her rather than selling her as a slave. In this context, she said: "If it was only I, she would be killed before she was sold... The slave of slaves was I! But a dead girl brings nothing. I would sell this girl for you to take you back to the land" (Buck, 1931).

O-lan's words came from the environment and the social customs she faced in the Chinese society where women have no place, especially the poor women who are mistreated. She preferred to kill her daughter rather than being sold as a slave. In the end, O-lan sacrificed her infant baby's life to save six lives, including her. Indeed, if she does not kill the baby, afterward due to lack of food, the baby will die.

Unfortunately, Wang Lung sold everything, except their land and the house, to his uncle at a lower price and immigrated to the south in search of food. After the war, Wang Lung managed to return to his land and rebuilt it again. Gradually, Wang Lung became a wealthy man; he began to see O-lan as: 
A dull and common creature, who plodded in silence without thought of how she appeared to others. He saw for the first time that her hair was rough and brown and unoiled and that her face was large and flat and coarse skinned, and her features too large altogether and without any sort of beauty or light . (Buck, 1931, p. 167)

pinpointing $O$-lan's sources of psychological trauma;

Lung considered her large and wide feet as a shame. He told her frankly, "Now anyone looking at you would say you were the wife of a common fellow and never of one who has land which he hires men to plow!. (Buck, 1931)

In this speech, Lung treated O-lan with scorn and contempt, neglecting her emotions that were negatively affecting her psyche.

Unfairly, Lung practiced a series of ingratitude and oppression against $\mathrm{O}$-lan forgetting her sacrifices in his complex and complicated times of famine and poverty. When he ordered her to serve his old and sick father, clean the house, cook, and help him in his land and to take care of the children, O-lan took the responsibility of paying attention to Wang Lung's father. She obeyed her husband when he told her: "take to my father first a bowl of hot water for his lungs"'(Buck, 1931, p. 25). He practiced masculine behavior, which known in the Chinese society as oppression. He believed that all of those activities are called the domestic-matters. Such matters that accompany marriage will be taken by women. He always assigned the serving role to his wife, forgetting her rights. Meanwhile, the man could change his life by marrying another beautiful woman to amuse him. Wang Lung used to find everything ready; he was always relaxed in his home as Buck maintained:

And then he lay in his bed warm and satisfied while in the kitchen the woman fed the fire and boiled the water. He would have liked to have slept, now that he could, but his foolish body, which he had made to arise every morning so early for all these years, would not sleep although it could, and so he lay there, tasting and savoring in his mind and in his flesh his luxury of idleness. (Buck, 1931, p. 26)

O-lan left her bed even after the child was born and went to help him in the field. O-lan centred all her power and strength to help her husband and family. She forgot about herself, getting only the neglect, suffering, and disloyalty. Although O-lan did everything in the house, Wang Lung controlled all the matters. He oppressed O-lan and forgot her happiness. He never appreciated her suffering from fatigue, aches and pains as she endured them silently.

Stating O-lan, lotus, and lung's aunt's role as representatives of different Chinese women;

Lung asked her uncle's wife to resolve his affair with new women quickly. His aunt advised him to marry instead of advising him not to marry again. She informed him "Only tell me which woman it is and I will manage the affair" (Buck, 1931). He answered unwillingly; he has never spoken her name aloud before this event, "it is the woman called Lotus" (Buck, 1931). His aunt played an essential role in settling his affair with Lotus. Although Wang Lung realized that his aunt is an untrusted woman, he took her advice in his affair.

Arab World English Journal for Translation \& Literary Studies 
One day Lung brought Lotus, the woman with a tiny feet and fair skin, to his home. He preferred Lotus, a prostitute, who used her beauty to lead a comfortable life . She always asked for expensive jewellery, clothes, and silver coins. She represented all greedy and stinginess. She also lacks the maternal instinct, complains and calls his children 'idiots'. Ironically Lung asked O-lan to arrange the matter with Lotus, and O-lan said, "Enough and enough! Am I a fool, or is this the first time I have managed a man and a maid? Leave me alone and I will do it" (Buck, 1931). Lung's act of bringing Lotus as a concubine is considered as a selfish and greed act. Lotus asked Lung about O-lan, imagining her as a maid in the house, but he did not know what to say. O-lan had hidden anger, sadness, and hopelessness. She was "winked them to hold back the tears, at last, she took the corner of her blue apron and wiped her eyes" (Buck, 1931), and she talked to herself, "it is a bitter thing in my house, and I have no mother's house to go back to anywhere" (Buck, 1931). Here, O-lan felt desperate for a refuge, but there was no place to go. O-lan lived as a marginalized wife in a very submissive way with her husband. It was excruciating that; she accepted the issue of her husband's second marriage, she felt disconnected and numb. She convinced herself with the fact that this is the nature of men in Chinese society. They used to take mistresses in time of wealth and relax only to belittle emotional pains. O-lan was a woman who bore her misfortune with equanimity. Nevertheless, she maintained her grief and sadness by doing the duties for her husband for her father-inlaw, as well.

Lung behaved in a very aggressive way when he said, "Now Lotus, my flower, and do not waste your sweetness on an old fat hag like that one. I need it for my own heart" (Buck, 1931). Lung also told Olan to give him the two pearls to provide them to Lotus. He said, "why should that one wear pearls with her skin as black as earth? Pearls are for fair women. And after an instant's silence, he cried out suddenly," give them to me I have need of them!" (Buck, 1931). Lung ordered O-lan to give him the pearls that she had stolen from the rich man's house, which he allowed her to save them. O-lan considered the pearls as an essential symbol, reflecting Lung's respect and consideration for his wife. However, he is in love with the young prostitute Lotus, and he wants to give her the pearls as a gift. This demand was the straw that broke the camel's back. It was the shock, and disbelief that her husband let her down. He neglected O-lan's feelings, causing her to feel the agony and suffering. Painfully, O-lan accepted the request:

Then slowly she thrust her wet wrinkled hand into her bosom and she drew forth the small package and she gave it to him and watched him as she unwrapped it; and the pearls lay in his hand and they caught softly and fully the light of the sun, and he laughed. But O-lan returned to the beating of his clothes and when tears dropped slowly, and heavily from her eyes, she did not put up her hand to wipe them away; only she beat the more steadily with her wooden stick upon the clothes spread over the stone. (Buck,1931 p.186)

Lung sounded selfish by taking the pearls, and laughed at their beauty. O-lan felt sad from his behavior and denial; she wept softly, and silently. O-lan remained to do her domestic burdensome, accepting the unbelievable pain. She worked hard without complaint only to forget Lung's indifference and condescension. She suffered deeply without informing anyone, a matter that led her to have emotional and physical exhausted.

Stating the way the causes of trauma might be the traumatic persons themselves;

Lately, Lung filled with remorse for his oppression of O-lan. He saw that her movements are painful and slow because O-lan became sick and stayed in her bed for months. He said to her to stay in bed and brought 
her a doctor. Hence, the doctor told him that O-lan is so sick and named an exorbitant fee to heal Olan. The doctor informed him that his wife's health is so bad and he cannot help her, telling him that O-lan will die. Suddenly, Lung hurried to the kitchen where Olan had lived her life. He remembered his bad and strict behavior towards her and so cried.

O-lan thought about her husband's status even in her last hours of life when her husband agreed to pay five hundred pieces of silver to the doctor for her treatment. She refused to spend the money for her recovery, telling him that her life is not worth it. She advised him to use money in buying a good piece of land. Although she was tired and sick, she secretly felt happy with his kindness. She has not seen his interest and sympathy since her marriage to him. According to her family, they also noticed the primary role of O-lan in the house during her sickness. O-lan asked Lung a final request; she preferred to celebrate with her son in his marrying ceremony before dying. During the wedding party, O-lan became very weak and unable to attend the ceremony, but she stayed in her bed listening to the party. At the last moment of her life, she expressed her feeling saying: "Well, if I am ugly, still I have borne a son; although I am but a slave there is a son in my house' and she said (...) Beauty will not bear a man son" (Buck, 1931, p.265). After long suffering with pain and neglect, O-lan died.

After her death, Lung's father died. Both O-lan and Lung's father buried during one funeral ceremony. Lung lived the grief, and pain when he sat beside two graves, and he "would not cry out loud as others for there no tears in his eyes, because to him that what had come about was come about, there was nothing to be done more than he had done" (Buck, 1931). Lung felt guilty and cruel in taking the pearls from his faithful wife, who stood by him and supported him through the complex and difficult times just because he wanted to satisfy his mistress Lotus. He "wished he had not taken the two pearls from Olan that day when she was washing his clothes at the pool, and he would never bear to see Lotus put them in her ears again" (Buck, 1931). As Lung walked away after the funeral ceremony, he had a terrible feeling that he cannot bear the torment of conscience, considering himself as a reason behind O-lan's death.

\section{Conclusions}

To answer the research question, which reads: What are the sources and types of psychological trauma experienced by the character O-lan, and later by the oppressors, her husband and his new wife, Wang Lung, in Buck's novel The Good Earth, the research concluded the following:

1. The role of status in society inflates the sense of marginalization that ultimately leads to psychological trauma. According to the culture in ancient Chinese, O-lan keeps silent and affords the marginalization of her husband. Lung was not satisfied with what he has. Although he has gained tremendous wealth, three good sons, and an obey wife. He also wants a concubine in his house. O-lan's heart is broken and disappointed with him, but she could not do anything. She hides her pain and agony till she died.

2. As far as the present work is concerned, there are two types of causes have led to experience psychological trauma: linguistic and behavioral causes, as indicated in the speech of Lung and his aunt.

3. The causer of trauma might experience trauma; as far as Lung experienced the psychological trauma , especially after O-lan's sickness. He felt sorry for his strict and harsh behavior with her. He finds himself living in a cage of remorse and heartbreak.

Arab World English Journal for Translation \& Literary Studies 
4. Psychological trauma can result from a rigid societal policy of oppressive and cruel procedure as Buck patriated them through his virtual literary Chinese characters. For instance, O-lan was depicted as a hardworker, a good housewife, unselfish, having resistance, and courage.

5. Such violent procedures can be applied on a personal or societal level by both genders as clearly represented by the literary characters Lung, Lotus, and Lung's aunt. Buck presented O-lan as a hard working who was struggling against famine, natural disaster, poverty, war, and corruption. She presented a sympathetic portrait of poor Chinese woman that ran true to rural existence. Buck portrayed the psychological trauma of O-lan based on the actual experiences that she has encountered in her life rather than fictional. Despite the scathing view towards women in general, one still can find women who have different types of control, authority, or level within the same Chinese community. This is because Chinese society highly believes in stratum distinction. Being a rich woman is something different from being a poor woman.

\section{About the Author:}

Hanan Abbas Hussein is an Instructor of literature at the University of Baghdad. She got her Master from the University of Baghdad in 2014. She is teaching Introduction to literature at the University of Baghdad/ Education for Women. She has participated in different workshops and symposiums in Iraq and published some articles in Journals. ORCID ID: https://orcid.org/0000-0002-3057-350X

\section{References}

Alongi. S. (2009). Introspection and Self-Transformation: Empathy in Toni Morrison's The Bluest Eye. Undergraduate Review, 5, 100-103.

Barker, R. L. (2003). The social work dictionary. (5th ed.). Washington, DC: NASW Press.

Blanchette, S. 2020. Critiquing psychiatry, narrating trauma: Madness in twentieth-century North

American literature and film century North American literature and film. Sarah, University of Western Ontario.

Buck, P.S. (1931). The good earth. New York: Washington Square press.

Heidarizadeh, H. (2015). The significant role of trauma in literature and psychoanalysis. Procedia-Social and Behavioral Sciences, 192, 788-795. https://doi.org/10.1016/j.sbspro.2015.06.093

Hwangbo. K. (2004). Trauma, narrative, the marginal self in selected contemporary American novels. a .Available at http://:etd.fcla.edu/UF/UFE0007302/hwangbo_k.pdf.Retrieved http://etd.fcla.edu/UF/UFE0007302/hwangbo_k.pdf 4

Peng, X. (2014). Chinese mother as other under patriarchy and racism the Chinese mothers' image in the joy luck club from the perspective of orientalism. European Journal of Business and Social Sciences, 2(10), 147-156.

Raton, B. (2018), What is trauma? Retrieved from http//www. centerforanxietydisorders.com Rebeca, L. (n.d.). The summery of Good Earth. Retrieved from http://www.gradesaver.com/the_good_earth/study-guide/shortsummary on 22/10/2020

Robinson. L, Smith, M. \& Segal. J. (2020). What is emotional and psychological trauma? Available at https://www.helpguide.org/articles/ptsd-trauma/coping-with-emotional-and-psychologicaltrauma.htm

Tamney, J. B., \& Chiang, L.H. (2002). Modernization, globalization and Confucianism in Chinese societies. Westport, CT: Praeger. Retrieved from www.helpguide.org/articles/ptsdtrauma/coping-with-emotional-and-psychological-trauma.htm 
AWEJ for Translation \& Literary Studies Volume, 5 Number 2. May 2021

Embodied Oppression and Psychological Trauma

Hussein

Yang, C. K. (1961). Religion in Chinese society: A study of contemporary social functions of religion and some of their historical factor. Berkeley and Los Angeles: University of California Press.

Yao, E.S.L.(1983). Chinese women: Past and present. Mesquite. TX: Ide House, Inc. 